Bioedusiana

Vol. 02, No. 01, Sep 2017

ISSN $2477-5193$

\title{
PERBEDAAN HASIL BELAJAR DAN KEMAMPUAN BERPIKIR KRITIS MAHASISWA PENDIDIKAN BIOLOGI DENGAN MENGGUNAKAN PEMBELAJARAN E-LEARNING DAN KONVENSIONAL
}

\author{
Suharsono $^{1)}$, Dani Ramdani ${ }^{1)}$, Liah badriah ${ }^{1)}$ \\ ${ }^{1}$ Jurusan Pedidikan Biologi Fakultas Keguruan dan Ilmu Pendidikan \\ Universitas Siliwangi Tasikmalaya \\ J1. Siliwangi No. 24 Kota Tasikmalaya 46115 \\ Email: suharsono@ymail.com
}

\begin{abstract}
This study aimed at investigating the differences between result study and critical thinking ability of biology students employing e-learning and konventional learning based on the digestive system concept. This study uses comparative research method, particularly posttest control group design. Besides, the population of this study the entire firs semester students of Biology Education Department, Faculty of Educational Sciences and Teachers' Training, Siliwangi University. Moreover, the sample of this study is two classes taken randomly by utilizing cluster random sampling, namely class $1 \mathrm{~A}$ consistof 30 students and 1B consist of 30 students. In addition, technique of collecting the data was conducted by giving the posttest to the students in order to obtain the data about students' final learning outcomes and applying rubric for the sake of identifying the students' critical thinking abilities. Likewise, T-Test (the test using to compare the differences of two scores average) with $(\alpha)=5 \%$ as the significant level was used. Referring to the data analysis and hypothesis testing, the results showed score sig. ( 2 tailed) is $0,690>0,05$ for result study and score sig. ( 2 tailed) is 0,83 $>0,05$ for critical thinking ability, based of resut analyze that there was a not significant learning outcome and critical thinking ability of Biology students employing e-learning and conventional learning.
\end{abstract}

Key Words: e-learning, conventional learning, result study and critical thinking ability.

\begin{abstract}
ABSTRAK
Penelitian ini bertujuan untuk mengetahui perbedaan hasil belajar dan kemampuan berpikir kritis mahasiswa biologi yang proses pembelajarannya menggunakan pendekatan e-learning dan konvensional pada konsep sistem pencernaaan makanan. Metode penelitian ini adalah metode komparatif yang menggunakan rancangan posttest control group design dengan populasi seluruh mahasiswa semester I program studi pendidikan Biologi FKIP UNSIL dengan sampel sebanyak 2 kelas yang diambil secara cluster random sampling yaitu kelas 1A sebanyak 30 orang dan kelas $1 \mathrm{C}$ sebanyak 30 orang. Teknik pengumpulan data dilakukan dengan memberikan posttest untuk memperoleh data kemampuan akhir hasil belajar dan rubrik untuk mengetahui kemampuan berpikir kritis mahasiswa, teknik analisis data yang digunakan adalah uji perbedaan dua rata-rata (uji-t) dengan taraf signifikan $(\alpha)=5 \%$. Berdasarkan analisis data dan pengujian hipotesis menunjukan nilai sig. ( 2 tailed) sebesar 0,690>0,05 untuk hasil belajar
\end{abstract}


Bioedusiana

Vol. 02, No. 01, Sep 2017

ISSN $2477-5193$

dan sig. (2 tailed) sebesar $0,83>0,05$ untuk berfikir kritis, dari data tersebut disimpulkan Ho diterima artinya tidak ada perbedaan yang signifikan hasil belajar dan kemampuan berfikir kritis mahasiswa biologi yang proses pembelajarannya menggunakan model pembelajaran e-learning dan konvensional.

Kata kunci : e-learning, pembelajaran konvensional, hasil belajar, kemampuan berfikir kritis

\section{PENDAHULUAN}

Ilmu Pengetahuan dan Teknologi (IPTEK) semakin lama semakin berkembang pesat. Perkembangan iptek ini tentunya memiliki dampak positif dan negatif bagi kehidupan manusia. Ilmu pengetahuan dan teknologi merupakan dua hal yang tidak dapat dipisahkan, keduanya akan saling menunjang. Perkembangan teknologi juga akan mampu meningkatkan perkembangan ilmu pengetahuan. Perkembangan teknologi telah memicu munculnya persaingan dalam berbagai bidang, salah satunya dalam bidang pendidikan.

Kehadiran Teknologi Informasi dan Komunikasi (TIK) dalam pembelajaran merupakan tantangan tersendiri bagi dunia pendidikan. Tuntutan dalam globalisasi, pendidikan telah hadir di depan mata. Berbagai perangkat komputer beserta koneksinya dapat menghantarkan peserta belajar secara cepat dan akurat apabila dimanfaatkan secara benar dan tepat. Teknologi menyediakan berbagai alternatif yang dapat digunakan untuk menyampaikan materi kepada peserta didik. Penggunaan media yang disediakan teknologi informasi merupakan salah satu usaha pengembangan kualitas pendidikan.

Menurut Purbowo (2002:1) "Pendidikan merupakan suatu proses komunikasi dan transfer informasi dari pendidik kepada peserta didik yang berisi informasi pendidikan, yang memiliki unsur pendidikan sebagai sumber informasi, sebagai media sarana penyampaian ide, gagasan, materi pendidikan serta peserta didik itu sendiri.

Proses pembelajaran akan menghasilkan hasil belajar.Hasil belajar inilah yang dijadikan kriteria dalam pencapaian tujuan pendidikan. Menurut Djamarah, Syaiful Bahri dan Aswan Zain (1997:119) "Hasil belajar merupakan kemampuan nyata yang dicapai seorang individu atau siswa setelah mengikuti kegiatan belajar yang proses pengukurannya menggunakan tes".

Hasil belajar peserta didik salah satunya dipengaruhi oleh media pembelajaran. Media pembelajaran yang berkaitan dengan pemanfaatan perkembangan teknologi adalah pemebelajaran e-leraning dengan menggunakan website. E-learning merupakan kegiatan pembelajaran yang memanfaatkan jaringan (internet, $L A N, W A N$ ) sebagai metode penyampaian, interaksi, dan 
fasilitasi serta didukung oleh berbagai bentuk layanan belajar lainnya. Secara sederhana dapat dipahami bahwa e-leraning ini terdiri dari aplikasi yang dapat digunakan sebagai alat bantu dalam kegiatan pendidikan. Salah satu aplikasi alternatif E-leraning yang bisa digunakan adalah Modular Object Oriented Dynamic Learning Environment (MOODLE).

MOODLE merupakan sebuah nama untuk sebuah program aplikasi yang dapat merubah sebuah media pembelajaran kedalam bentuk website. Aplikasi ini memungkinkan peserta didik untuk masuk kedalam ruang kelas digital untuk mengakses materi-materi pembelajaran. Dengan menggunakan MOODLE, kita dapat membuat materi pembelajaran, kuis, jurnal elektronik dan lain-lain (Renaldo, Ferri, 2009).

Berdasarkan hasil observasi yang telah dilakukuan pada mahasiswa program studi pendidikan biologi tingkat I semester 1 ditemukan permasalahan dalam kegiatan pembelajaran dikelas pada konsep sistem pencernaan pada manusia rata-rata mahasiswa kurang begitu mampu dalam mengembangkan kemampuan berpikir kritis serta penguasaan konsepnya pun belum begitu memuaskan dengan perolehan nilai pada konsep tersebut

\section{METODE PENELITIAN}

Metode yang digunakan dalam penelitian ini adalah metode komparatif dengan menggunakan pendekatan kuantitatif. Penelitian komparatif adalah Penelitian komparatif adalah penelitian yang membandingkan keberadaan satu variabel atau lebih pada dua atau lebih sampel yang berbeda, atau pada waktu yang berbeda (Sugiyono, 2006).

\section{Variabel Penelitian}

Dalam penelitian yang ini, yang menjadi variabelnya adalah :

1. hasil belajar mahasiswa(Y1) serta Kemampuan berpikir kritis (Y2) sebagai variabel terikat.

2. Pembelajaran e-learning dan konvensional (X) sebagai variabel bebas.

\section{Desain Penelitian}

Dalam penelitian ini, disain penelitian yang digunakan adalah postest one group desain, peneliti mengadakan treatment dua kali yang diperkirakan sudah mempunyai pengaruh kemudian diadakan post test. Adapun disain penelitian menurut Arikunto, Suharsimi (2006:85) yaitu:

rancangan : kelas eksperimen I :

$$
\mathrm{R} \quad \mathrm{X} \quad \mathrm{O}
$$

kelas kontrol II :

$\mathrm{R} \mathrm{O}$

prosedur : subjek diberi perlakuan $\mathrm{X}$ dan setelah dilakukan pengukuran $(\mathrm{O})$ sebagai akibat dari perlakuan yang diberikan

keterangan:

$\mathrm{R}$ : Random

$\mathrm{X}$ : perlakuan (treatment) pertama dengan menggunaka 
pembelajaran e-learning dan observasi berpikir kritis.

$\mathrm{O}$ : pencapaian kelompok sampel setelah perlakuan untuk hasil belajar.

\section{Teknik Pengumpulan Data}

Pengumpulan data dilakukan dengan beberapa cara yaitu:

1. Tes

Tes yang digunakan yaitu tes individual dalam bentuk multiple choice yang diberikan setelah proses belajar mengajar selesai.

2. Non-tes

Format observasi selama pembelajaran berlangsung, untuk menjaring tingkat kemampuan berpikir kritis mahasiswa digunakan indikator kemampuan berpikir kritis peserta didik menurut ennis (fiser, 2009).

\section{Analisis Data}

Teknik analisis data yang dilakukan adalah analisis komparatif. Analisis deskriptif dilakukan dengan menyajikan data penelitian yang berupa deskripsi data analisis komparatif digunakan untuk menguji hipotesis.

Sebelum analsis hipotesis dilakukan, maka diperlukan pengujian beberapa persyaratan yang harus dipenuhi. Persyaratan analisis yang harus di penuhi adalah :

1. Uji normalitas rata,
menggunakan $\begin{array}{r}\text { dajgujian } \\ \text { Kolmogorov-Smirnov dengan }\end{array}$
kriteria jika nilai asymp. Sig (p)
$>\alpha$, maka sebaran data
berdistribusi normal.

2. Uji Homogenitas. Uji Homogenitas digunakan sebagai bahan acuan untuk menentukan keputusan uji statistik. Adapun dasar pengambilan keputusan dalam uji homogenitas adalah :

a) Jika nilai signifikansi $<0,05$, maka dikatakan bahwa varian dari dua atau lebih kelompok populasi data adalah tidak sama.

b) Jika nilai signifikansi $>0,05$, maka dikatakan bahwa varian dari dua atau lebih kelompok populasi data adalah sama.

\section{HASIL DAN PEMBAHASAN}

Data hasil penelitian yang disajikan meliputi data hasil belajar berupa posttest mahasiswa berdasarkan instrumen-instrumen yang telah dilakukan uji validitas serta uji reliabilitasnya dan hasil skor berpikir kritis mahasiswa berdasarkan rubrik yang telah disediakan.

Berikut dikemukakan data untuk masing-masing kelas :

\section{Hasil Belajar Mahasiswa}

Data hasil belajar meliputi data postest untuk pembelajaran yang menggunakan pembelajaran elearning dan konvensional yang terdiri dari 40 soal pilihan ganda yang valid dan reliabel. Jumlah mahasiswa di kelas masing-masing sebanyak 30 orang. Ringkasan lampiran tersebut tersaji pada tabel 1 . 
Tabel 1. Ringkasan perhitungan hasil belajar

\begin{tabular}{l|r|r|r|r|r}
\hline & \multicolumn{1}{|c|}{$\mathrm{N}$} & \multicolumn{1}{c|}{ Mean } & \multicolumn{1}{c|}{$\begin{array}{c}\text { Std. } \\
\text { Deviation }\end{array}$} & Minimum & Maximum \\
\hline Kelas A & 30 & 29.5667 & 6.68856 & 16.00 & 40.00 \\
Kelas C & 30 & 28.8333 & 7.46062 & 11.00 & 40.00 \\
\hline
\end{tabular}

\section{Kemampuan Berfikir Kritis}

Data kemampuan berpikir kritis mahasiswa biologi yang pembelajarannya menggunakan pendekatan induktif diperoleh dengan menggunakan rubrik penilaian berpikir kritis yang penilainyya dilakukan saat pembelajaran berlangsung yang terdiri dari 4 indikator. Berdasarkan indikator dan penilaian yang tersedia dalam rubrik maka diperoleh data yang terlampir yang tersaji dalam Tabel 2.

Tabel 2. Ringkasan perhitungan kemampuan berpikir kritis

\begin{tabular}{l|r|r|r|r|r}
\hline & \multicolumn{1}{|c|}{$\mathrm{N}$} & \multicolumn{1}{c|}{ Mean } & \multicolumn{1}{c|}{$\begin{array}{c}\text { Std. } \\
\text { Deviation }\end{array}$} & Minimum & Maximum \\
\hline Kelas A & 30 & 10.0167 & 3.06955 & 4.00 & 15.00 \\
Kelas C & 30 & 9.8500 & 2.96284 & 4.00 & 15.00 \\
\hline
\end{tabular}

\section{Pengujian Hipotesis}

Pengujian hipotesis dalam penelitian ini meliputi uji beda $\mathrm{t}$ testi. Perhitungan analisauji beda ttest dilakukan dengan bantuan program SPSS 21. Adapun pengujian hipotesis-langkahlangkah uji hipotesis dapat dijelaskan sebagai berikut:

\section{Hipotesis pertama}

H0 : Tidak ada perbedaan hasil belajar mahasiswa biologi yang menggunaan e-learning dengan menggunakan pembelajaran konvensional pada konsep sistem pencernaan.
Ha : Ada perbedaan hasil belajar mahasiswa biologi yang menggunaan e-learning dengan menggunakan pembelajaran konvensional pada konsep sistem pencernaan.

Berdasarkan hasil uji beda t-test untuk mengetahui perbedaan kedua pendekatan hasil belajar tersaji secara ringkas pada Tabel 3. 
Bioedusiana

Vol. 02, No. 01, Sep 2017

ISSN $2477-5193$

Tabel 3. Rangkuman Uji Beda t-test Hasil Belajar Mahasiswa Pendidikan Biologi

\begin{tabular}{lllllr}
\hline \multicolumn{7}{c}{ Group Statistics } \\
\cline { 2 - 7 } & KELAS & $\mathrm{N}$ & \multicolumn{1}{c}{ Mean } & Std. Deviation & Std. Error Mean \\
\hline \multirow{2}{*}{ NILAI_HB } & KELASA & 30 & 29.5667 & 6.68856 & 1.22116 \\
& KELASC & 30 & 28.8333 & 7.46062 & 1.36212 \\
\hline
\end{tabular}

\begin{tabular}{|c|c|c|c|c|c|c|c|c|c|c|}
\hline \multicolumn{11}{|c|}{ Independent Samples Test } \\
\hline & & \multicolumn{2}{|c|}{$\begin{array}{l}\text { Lexene's. } \\
\text { Test for } \\
\text { Equality of } \\
\text { Variances }\end{array}$} & \multicolumn{7}{|c|}{ t-test for Equality of Means } \\
\hline & & \multirow[t]{2}{*}{$\mathrm{F}$} & \multirow[t]{2}{*}{ Sig. } & \multirow[t]{2}{*}{$\mathrm{t}$} & \multirow[t]{2}{*}{ df } & \multirow[t]{2}{*}{$\begin{array}{l}\text { Sig. (2- } \\
\text { tailed) }\end{array}$} & \multirow[t]{2}{*}{$\begin{array}{c}\text { Mean } \\
\text { Difference }\end{array}$} & \multirow[t]{2}{*}{$\begin{array}{l}\text { Std. Error } \\
\text { Difference }\end{array}$} & \multicolumn{2}{|c|}{$\begin{array}{l}95 \% \text { Confidence } \\
\text { Interval of the } \\
\text { Difference }\end{array}$} \\
\hline & & & & & & & & & Lower & Upper \\
\hline \multirow{2}{*}{ NILAI_HB } & $\begin{array}{l}\text { Equal variances } \\
\text { assumed }\end{array}$ & .299 & .587 & .401 & 58 & .690 & .73333 & 1.82937 & -2.92855 & 4.39521 \\
\hline & $\begin{array}{l}\text { Equal variances } \\
\text { not assumed }\end{array}$ & & & .401 & 57.321 & .690 & .73333 & 1.82937 & -2.92947 & 4.39614 \\
\hline
\end{tabular}

Berdasarkan hasil pada keluaran SPSS 21, Independent Samples Tes kolom ttest for Equality of Means, skore sig. (2 tailed) sebesar 0,690. Berdasarkan kriteria, bila nilai sig. (2 tailed) > 0,05 maka Ho diterima. Hal ini berarti tidak terdapat perbedaan yang signifikan hasil belajar mahasiswa yang proses pembelajarannya menggunakan elearning dan pembelajaran konvensional pada konsep sistem pencernaan.

\section{Hipotesis kedua}

H0 : Tidak ada perbedaan kemampuan berfikir kritis mahasiswa biologi yang menggunaan e-learning dengan menggunakan pembelajaran konvensional pada konsep sistem pencernaan.

Ha : Ada perbedaan kemampuan berfikir kritis mahasiswa biologi yang menggunaan elearning dengan menggunakan pembelajaran konvensional pada konsep sistem pencernaan.

Berdasarkan hasil uji beda t-test untuk mengetahui perbedaan kedua pendekatan hasil belajar tersaji secara ringkas ada Tabel 4. 
Tabel 4. Rangkuman Uji Beda t-test Hasil Berfikir kritis Mahasiswa Pendidikan Biologi

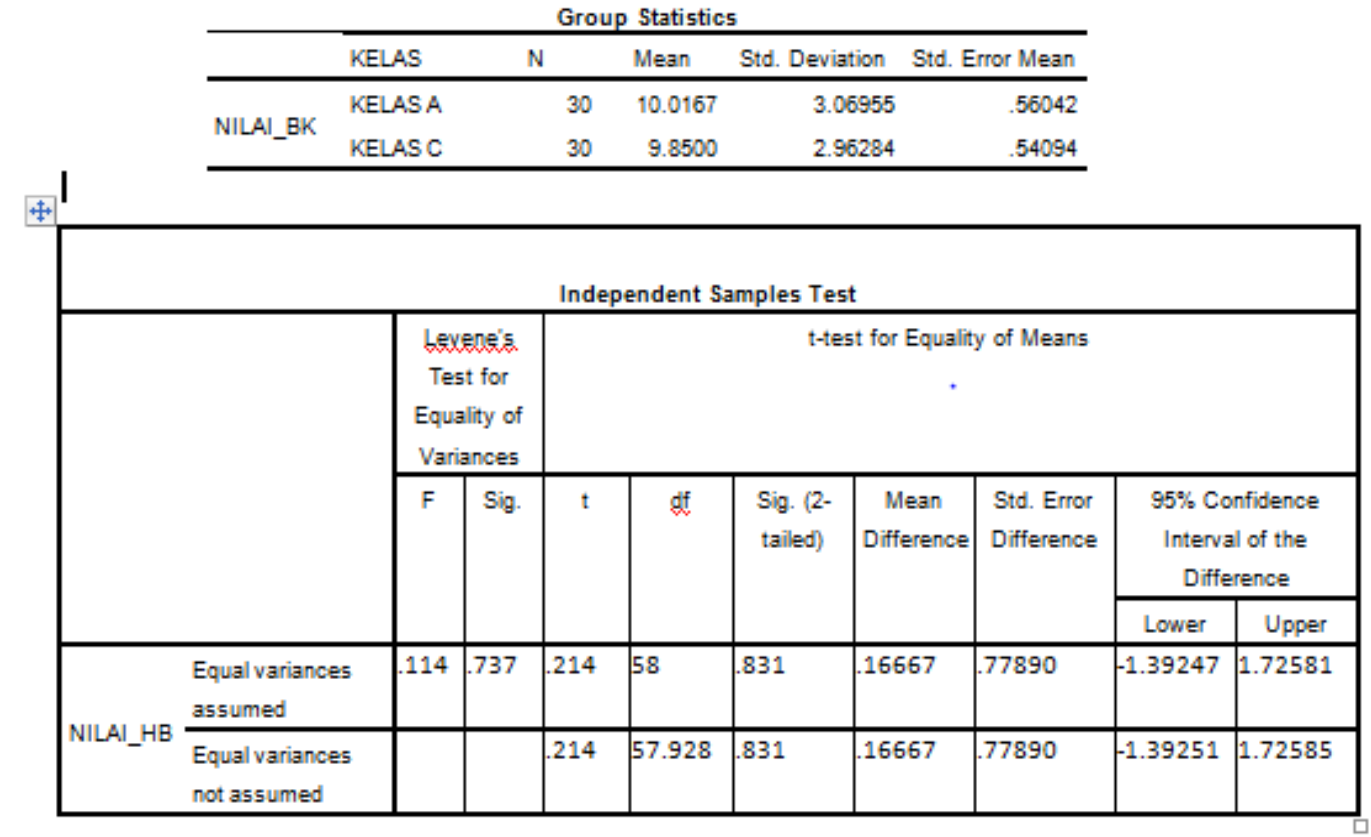

Berdasarkan hasil pada keluaran SPSS 21, Independent Samples Tes kolom t-test for Equality of Means, skore sig. (2 tailed) sebesar 0,737 . Berdasarkan kriteria, bila nilai sig. (2 tailed) > 0,05 maka Ho diterima. Hal ini berarti tidak terdapat perbedaan yang signifikan kemampuan berpikir kritis mahasiswa yang proses pembelajarannya menggunakan elearning dan pembelajaran konvensional pada konsep sistem pencernaan makanan.

Berdasarkan hasil analisis dalam penelitian ini mahasiswa yang proses pembelajarannya baik yang menggunakan pembelajarn elearning atau pun pembelajran konvensional ternyata tidak memberikan perbedaaan hasil belajar dan kemampuan berfikir kritis yang signifikan, dilihat dari nilai sig yang keduanya menunjukan > dari 0,05 , selain itu diperkirakan dari hasil tijauan pustaka yang dilakukan pembelajaran berbasis elektronik ini ternyata tidak membebankan mahasiswa karena proses belajar bisa dilakukan dimana saja dan kapan saja, sehingga hal ini memberikan rasa nyaman (enjoy), sehingga proses pemahaman konsep lebih mudah untuk dipahami.

Dalam penelitian ini, kemampuan berfikir kritis mahasiswa yang diberi perlakuan yang berbeda tenyata memberikan hasil yang sama, hal ini dikarenakan baik ada atau tidak adanya dosen dikelas ternyata proses diskusi tentang materi ini masih bisa dilakukan secara maksimal, seperti pada e-learning ada kolom chatting yang bisa diikuti oleh seluruh mahasiswa yang ingin berdiskusi baik dengan dosen atau mahasiswa lainnya, hal ini memberikan makna yang sama seperti kegiatan diskusi 
yang biasa dilakukan pada kelas konvensional.

\section{PENUTUP}

\section{Simpulan}

Berdasarkan penelitian, pengolahan data, dan pengujian hipotesis, maka penulis berkesimpulan bahwa tidak terdapat perbedaan hasil belajar dan kemampuan berfikir kritis mahasiswa biologi yang menggunaan e-learning dengan menggunakan pembelajaran konvensional pada konsep sistem pencernaan manusia.

\section{Saran}

Berdasarkan hasil penelitian yang telah dilakukan, maka penulis menyarankan:

1. Pembelajaran e-learning dan konvensional bisa menjadi salah satu rujukan pembelajaran yang bisa digunakan oleh dosen/guru untuk meningkatkan hasil belajar dan kemapuan berfikir kritis

2. Pembelajaran e-learning bisa digunakan sebagai pembelajaran alternatif apabila dosen/guru tidak dapat bertatap muka dengan mahasiswa dikelas, dikarenakan memberikan pengaruh yang sama terhadap hasil belajar dan kemapuan berfikir kritis.

3. Penggunaan pembelajaran elearning dan konvensioanal ini bisa digunakan pada konsep dan matakuliah yang lain, namun keberhasilannya sangat tergantung dari peranan dosen.

\section{DAFTAR PUSTAKA}

Achmad, Arief. 2007. Memahami berpikir kritis. [online]. Tersedia :http://reaschengines.com/1007ar ief3.html. [7 April 2016]

Anderso. Lorin W.; Krathwohl, David R ; Arisanian, Peter W.; Cruikshank; Kathleen A.; Mayer, Richard E.; Paul R.; Raths, James; dan Wittrock, Merlin C. (ed) (2001). A Taxonomy for Learning Teaching and Assessing A revision of Bloom's Taxonomy of Educational Objectivities. Abridged Edition. New York : Longman Inc. Arikunto, Suharsimi. 2010. Prosedur Penelitian Suatu Pendekatan Praktek. Jakarta, Rineka Cipta.

Campbell, N.A., Reece., J.B.Urry, L.A., Wasserman, A.A., Minorsky, P.V., dan Jackson, R.B. (2008c). Biologi Jilid 3. (Edisi Kedelapan). Jakarta : Erlangga.

Djamarah, Bahri Syaiful dan Zain, Aswan. 2010. Strategi Belajar

Mengajar. Jakarta: Rineka Cipta.

Ficher, Alec. 2009. Berpikir Kritis Sebuah Pengantar. Jakarta : Erlangga.

Jalaludin. 2013. Filsafat Ilmu

Pengetahuan. Depok: PT. Rajagrafindo Persada.

Liliasari. (2009). Berpikir Kritis Dalam Pembelajaran Sains Kimia Menyju Profesionalisme Guru. [online]. Tersedia: http://file.upi.edu/direktori/PRO DI.PENDIDIKAN_IPA/1949092 71978032- 


\section{LILIASARI/BERPIKIR_KRITI}

S_Dlm_Pembel_09.pdf

$[13$

Agustus 2016]

Muhibbin Syah. (2003). Psikologi

Belajar. Jakarta: PT. Raja

Grafindo Persada.

Purbo. 2002. Flash Design dan Animasi Web. Jakarta: Elex Media Komputindo.

Renaldo, Ferri. 2009. Moodle dan

Fitur-fiturnya. [online] tersedia di: http://ilmukomputer.org/wpcontents/uploads/20099/02/ferrifiturmoodle.pdf. (26/110/2016)

Ruseffendi. 2010. Dasar-dasar

Penelitian Pendidikan dan Bidang Non Eksakta Lainnya. Bandung : Tarsito.

Sugiyono. 2012. Metode Penelitian

Kuantitatif, kulaitatif dan $R \& D$, Bandung : Alpfabeta
Sukari.2011. Learning Management System ElearningPro. [online] tersedia di: http://www.pasweb.com/LMS/L earningManagementSystemElear ningProPortalPaketAplikasiSeko lahPASberbasisWeb.htm. (20/10/2016)

Suwartono. 2014. Dasar-Dasar Metodologi Penelitian.

Yogyakarta: Andi Yogyakarta

Wahono, R.S. 2009. System elearning berbasis model motivasi komunitas [online] tersedia di: http://ilmukomputer.org/wpcontents/uploads/2007/10/romimodelmotivasikomunitas3oktober2007.zip. (26/10/2016) 